\title{
Nature, Knowledge, and Civilisation. Connecting the Atlantic and Pacific Worlds in the Enlightenment
}

\author{
S A R A H IR VING-STONEBRAKER* \\ E-mail: s.irving@westernsydney.edu.au
}

\begin{abstract}
A central feature of Scottish Enlightenment thought was the emergence of stadial or "conjectural" theories of history, in which the development of all human societies, from those in Europe, to the Seminole Indians in Florida and the Tongans of the South Pacific, could be understood and compared according to the same universal historical criteria. This paper argues that central to this tradition was an account of the relationship between "useful knowledge" and social development. This article argues that we can map the circulation of a discourse about useful knowledge, nature, and civilisation through a network of Scottish-trained physicians and naturalists that spread to the Atlantic and to the Pacific. In the Atlantic world, physicians and naturalists used the vocabulary and categories of stadial theory to classify indigenous societies: they made comparisons between the illnesses that they thought "naturally" afflicted savage cultures, as opposed to those of civilized Europeans. In the Pacific, the Edinburgh-trained surgeons and naturalists compared Tahitians, Maoris, and Australian Aborigines to black Africans and Europeans, and they commented on the presence or absence of useful knowledge as a marker of the degree of development of each civilisation.
\end{abstract}

Keywords: Nature, knowledge, civilisation, Atlantic, Pacific.

"It is gratifying . . . to observe that the same means which . . elevate us above the savage, viz, the progress of civilization and refinement, have led to banish the most loathsome and malignant distempers, [and] to prolong life." ${ }^{1}$ In the eyes of Edward Miller, a physician born in Delaware in 1760, the advancement of society-its progress towards civilization - resulted in the gradual improvement of human health. Miller was writing an appendix to the third edition of Robert Thomas's The Modern Practice of Physic (1811), a book that was widely received, exhausting an edition almost every two years during its first decade of publication. Miller was exploring the relationship between the improvement of medical knowledge and the progress of civilization. 
His interest in this connection was shaped by his education in the eighteenth century Scottish Enlightenment, which pioneered a series of theories about the relative developmental stages of human societies. Adam Smith, Adam Ferguson, and others identified various criteria that defined the stages of civilisation. Central to these criteria, but as yet largely unrecognised by historians, was an emphasis on the ability of a society to pursue particular types of knowledge - principally what they identified as "useful" knowledge - as one of the hallmarks of civilisation.

This interest in defining progress was one of the quintessential features of the Scottish Enlightenment. During the eighteenth century, something of a global consciousness of the markers of human difference emerged. There was a sense in which all societies-from Europeans, to the Seminole Indians in north Florida, to the Tongans in the South Pacificcould be understood, and compared, according to the same universal historical criteria. Central to this tradition was an account of the relationship between useful knowledge and social development, and that these ideas were forged in an increasingly global context. Scottish trained naturalists and physicians spread from Scotland into the Atlantic and the Pacific, using stadial ideas about progress to render non-European societies, in their so-called "natural" state, intelligible. I argue that the idea of useful knowledge provides a connection between Scottish historical theorising and the ethnographic observations of medical practitioners on the Atlantic and Pacific peripheries.

The first part of this article explores the genesis of ideas about the relationship between the "natural condition," useful knowledge, and social development in the Scottish Enlightenment. I then trace the development of these ideas through networks of naturalists and physicians trained in Scotland, and who spread to the Atlantic and the Pacific worlds in the late eighteenth and early nineteenth centuries. In the Atlantic world, I explore a network of physicians who were trained in Edinburgh but brought their medical and natural history training to Philadelphia and New York in the late eighteenth century. Influenced not only by the famous physician William Cullen, but also by the stadial theory of Adam Smith and his colleagues, they keenly observed the diseases and natural remedies of Native Americans, and commented on the relationship between the cultivation of useful medical knowledge and the civilising progress of societies. The article then shifts to the Pacific, where Scottish-trained surgeons and naturalists such as William Anderson and Peter Cunningham observed the various degrees of civilisation of the indigenous cultures they encountered, and assessed those cultures' ability (or inability) to pursue useful knowledge.

\section{Scotland and the World}

In the eighteenth century, a particular narrative emerged about the character and purpose of useful knowledge. This narrative was grounded in a historical story about the way in which the pursuit of knowledge is related to the development of human society. Since the ancient world, there had existed a strand of natural history that encompassed not just what we would now conceive of as nature as a biological category, but also human cultures, with their varying customs and practices. Although this tradition dates 
to Pliny the Elder in the first century AD, it was transformed by the early modern European discovery of the Americas, when the genre of natural history writing swelled with accounts from these hitherto unknown places. ${ }^{2}$ Pliny's Natural History, in many ways one of the most important models for early modern natural history writing, explored human societies and their customs, particularly those of the Scythians and Ethiopians, under the heading "Of the Nature of Man," in Book $7 .{ }^{3}$ It was also human customs that sparked much of the interest of early modern writers about the Americas.

José de Acosta's Natural and Moral History of the Indies (1590) and Gonzalo Fernández de Oviedo's General and Natural History of the Indies $(1535,1557)$ made observations about various aspects of the indigenous cultures they encountered. De Acosta, for example, detailed the religious festivals and marriage rituals of the Mexicans in book 5, as well as the arts, handicrafts, and government of the Incas in book $6 .{ }^{4}$ Likewise, Oviedo described the inventions of the canoe and the hammock, and the fishing methods of the Cubans, for example. ${ }^{5}$ Likewise, Francis Bacon, in his essay "Of Travel," makes suggestions to travellers about how to observe other cultures while travelling, including advising that young travellers take note of the institutions of human society: "the churches and monasteries ... havens and harbours; antiquities and ruins; libraries; colleges . . . armories; arsenals; magazines . . . treasuries of jewels and robes; cabinets and rarities." 6

In the eighteenth century, the development of knowledge became one of the attributes of human societies that natural historians and philosophers took as their subject matter. The leading Scottish practitioners of stadial history in the Scottish Enlightenment-Adam Ferguson, William Robertson, John Millar and Lord Kames - began to tell a historical story (rather than a sacred history) about knowledge: its origin, its purpose, and its relationship to civil society. They were particularly interested in useful knowledge, a term they used frequently.

In the work of Scottish Enlightenment thinkers, it is clear that humanity's pursuit of knowledge, and in particular the capacity to use knowledge in practical ways, is viewed as a universal possibility in all human societies. To these thinkers, the capacity to pursue useful knowledge is universal because it is a natural capacity. In his Essay on the History of Civil Society, Adam Ferguson commented that man is "an artificer of his own frame, as well as of his fortune, and is destined, from the first age of his being, to invent and contrive." This capacity, Ferguson argued, is "natural to man."7 Notice that his emphasis here is not just upon knowledge, but also upon the importance of using knowledge to intervene in the world.

A central tenet of Ferguson's thought is that, while humanity's capacity to use knowledge to improve its condition is natural and universal, it is only properly pursued and realized in a particular form of civilized society. Ferguson held that there is a distinction between on the one hand, "rude" societies, who merely enact their natural capacity, and on the other hand, the cultivation of useful knowledge made possible by a path of historical development. In his Essay on the History of Civil Society, he reflected upon the growth of science. "The latest efforts of human invention are but a continuation of certain divides which were practiced in the earliest 
ages of the world, and in the rudest state of mankind. What the savage projects, or observes, in the forest, are the steps which led nations, more advanced, from the architecture of the cottage to that of the palace, and conducted the human mind from the perceptions of sense, to the general conclusions of science." ${ }^{8}$ In the eighteenth century, the term science did not denote the discipline of modern science as we understand it today. Rather, science still possessed its Latin meaning from scientia; the meticulous and systematic pursuit of knowledge.

But what did Ferguson and his fellow Scottish thinkers believe were the types of society that could cultivate useful knowledge properly? There was a consensus that a constellation of social and historical conditions was necessary. There was, first, the need for a division of labour, such that there existed a class of people who were able to be "fond of useful knowledge," as Lord Kames put it in the Preface to his famous Sketches of the History of Man. This class of people would be free from both luxury, which would breed indolence, and "the depression of bodily labour." "Closely related to this was the possession of private property, which would be guaranteed by a stable political regime. As Ferguson put it, "when possessed of property and settlement, [societies] set the example of a lively invention, and superior ingenuity in the practice of arts and the study of science." ${ }^{10}$ Other notable accoutrements of civil society were indispensable for the proper cultivation of useful knowledge. A sphere of public discourse, for example, and the "invention of the art of printing" were, in Adam Smith's mind, the means by which "a man of letters could . . . communicate [useful knowledge] to other people." 11

Particularly intriguing is the way in which the development of this conception of "useful knowledge" was not a European one, but rather, involved the attempt to render non-European societies intelligible. It is precisely because naturalists and physicians around the Atlantic and Pacific saw the rudiments of useful knowledge existing "naturally" in what they called barbarous cultures that they developed their conception of the kinds of societies that could properly pursue useful knowledge. Benjamin Rush, the most famous physician in eighteenth-century America, for example, investigated Native Americans' remedies for smallpox. He was convinced that Native Americans possessed some elements of useful knowledge, but their problem was that they just could not use it properly.

It is my contention that if we map this discourse about useful knowledge, nature, and civilisation in the late eighteenth and early nineteenth centuries, we can identify a number of nodes on an increasingly global network. Naturalists and physicians trained at the University of Edinburgh, the home of Scottish Enlightenment stadial theory, were particularly mobile. They spread first across the Atlantic to North America, and then others journeyed to the South Pacific, Australia, and New Zealand. In the Atlantic world, physicians and naturalists used the vocabulary and categories of stadial theory to classify indigenous societies. They cited Adam Smith; they made comparisons between the illnesses that they thought "naturally" afflicted savage cultures, as opposed to those of civilized Europeans; and they made comments about how diseases changed as societies became more civilized. In the Pacific, Edinburgh-trained surgeons and 
naturalists compared Tahitians, Maoris, and Australian Aborigines to black Africans and Europeans, and they commented on the presence or absence of useful knowledge as a marker of the degree of development of each civilisation.

This article develops two strands of recent scholarship: the first places the Atlantic world in the context of global history, and the second explores the intellectual geography of the Scottish Enlightenment. Scholars of the Atlantic world are becoming interested in tracing the connections between the Atlantic world and global systems of trade, material and ideational exchange that emerged in the early modern period. Jorge Cañizares-Esguerra, Erik Seeman, Nicholas Canny, and others have recognised that, as much as the Atlantic world is a useful category to signify that the continents that bordered the Atlantic Ocean - the Americas, Europe, and Africa - constituted a sphere of interaction, it is fruitful to understand the ways in which the Atlantic region was itself connected to other parts of the globe. ${ }^{12}$ Thus far, however, few scholars have explored the relationships between the Atlantic and the Pacific. This is quite possibly because of the geographic location of most Atlantic historians. ${ }^{13}$ There is, however, a burgeoning intellectual history of the Pacific world, pioneered by John Gascoigne and others. For the most part, their work attempts to understand the Pacific primarily in the context of the European Enlightenment and British imperial history. ${ }^{14}$

By exploring the nexus between Scottish thought and the medical observation of indigenous societies, this article develops a current strand of scholarship interested in the connections between Enlightenment natural history, Scottish stadial theory, and European imperialism. Notable examples of this include Fredrik Albrittson Jonsson's recent book Enlightenment's Frontier explores the environmental roots of the Scottish Enlightenment, while Linda Andersson Burnett and Silvia Sebastiani's work explores the transformation of stadial ideas on progress, and the way those ideas were shaped by a growing interest in natural history, as well as by contact with indigenous peoples in a variety of colonial contexts. ${ }^{15}$ Sankar Muthu's recent study of Adam Smith has pointed out that occasionally, it was possible to mobilise different elements of Enlightenment theory to critique particular imperial policies and practices. ${ }^{16}$

This article aims to extend the current scholarship on the intellectual geography of the Scottish Enlightenment in two ways. First, I explore the importance of useful knowledge and its relationship to social development, arguing that the concept of useful knowledge was the nexus between Scottish stadial theories of history, and Scottish medical discourse, as the two were employed along the Atlantic and Pacific peripheries. Second, I show that, during the eighteenth-century, some stadial theorists could acknowledge the merits of the knowledge accumulated by indigenous cultures. As the nineteenth century wore on, though, this recognition faded.

\section{The Atlantic World}

The University of Edinburgh revolutionised medical training in the eighteenth century. In contrast to the existing system of private lectures and hospital schools, Edinburgh physicians developed a new model that consisted of "a complete medical 
faculty associated with a university." ${ }^{17}$ Under three generations of leading physicians all named Alexander Monro-I, II, and III-the Medical School at the University of Edinburgh emerged as a distinctive model that its alumnae transported across the Atlantic, and later, across the Pacific as well. Between 1782 and 1784, Edward Miller, whose comments about the happy conjunction of civilization and health began this article, attended the College of Medicine at the University of Pennsylvania. Miller was already a surgeon's mate, and after serving in the Revolutionary War, he travelled to Philadelphia to attend the lectures of some of the most eminent physicians in the new Republic of the United States. This intimate group of physicians are now famous names in the history of medicine. They included Benjamin Rush, John Redman, John Morgan, and Adam Kuhn. Rush, for example, was professor of chemistry, and went on to become a founding father, a signatory of the Declaration of Independence, and, arguably, the preeminent physician in early American history.

What Rush and his colleagues at the medical school held in common was their training: they had all been educated at the University of Edinburgh. They were the second generation of a network of Edinburgh physicians who had transplanted the Edinburgh model of medical education, together with its emphasis on the teaching of human anatomy, across the Atlantic. Founded in 1765, the medical school at the University of Pennsylvania was the first in North America. There was also another group of former Edinburgh students, including Peter Middleton and Ezekiel Ostrander, who used this same structure as the basis of the curriculum at the College of Medicine at King's College (later Columbia University), in New York. These medical schools, both structured on the Edinburgh model, form two nodes on this network, and their physicians were in close contact with one another. In addition to this institutional legacy, Scotland had another kind of influence on this Atlantic network of naturalists and physicians. Scottish social thought shaped these physicians' interpretations of the variety and distribution of diseases, and remedies, they observed among the inhabitants of North America.

In 1774, Benjamin Rush gave an anniversary oration to the American Philosophical Society entitled "An Inquiry into the Natural History of Medicine among the Indians of North America, and a Comparative View of their diseases and remedies, with those of civilized nations." Rush began his explanation of the natural historical differences between native Americans and Europeans by noting the classic stadial taxonomy of human society. "Civilians have divided nations into savage, barbarous and civilized," he wrote. "The savage, live by fishing and hunting. The barbarous, by pasturage and cattle; and the civilized by agriculture." ${ }^{18}$ Although recognizing that American Indians cultivated maze, Rush argues that they "partake chiefly of the manners of savages." 19

Rush was convinced that a society's diseases were influenced by two natural factors: climate and the society's customs (or "manners," as he put it). Stadial theory did important intellectual work for Rush. It provided an explanation of the way in which both these factors influenced disease: stadial theory attributed a powerful role 
to climate, and it also posited that a society's customs are characteristic of its particular stage of development. When Rush described the customs of the native Americans, he paid particular attention to both climate and manners. He outlined their diet, their pregnancy and childbirth practices, their sleeping habits, and the relationships between the sexes. In all these facets of life, Rush observed that the Indians were ascetic. Life was harsh. He drew upon Adam Smith's Theory of Moral Sentiments to juxtapose the Indians' way of life to that of civilized societies. "The weakness of life (says Doctor Adam Smith) which is so much indulged in ages of humanity and politeness, is regarded among savages as the most unpardonable effeminacy." 20 The particular types of Indians' diseases, Rush argued, are directly related to their savage habits. So, for example, the Indians are unaffected by mental illness, because the phenomenon of mental illness was one of the physiological consequences of modern, civil societies. ${ }^{21}$ Rush claimed that he has not been able to find "a single instance of madness, melancholy or fatuity among the Indians." 22

Rush also observed that "fevers constitute the only diseases among the Indians." 23 We should note that in the eighteenth century, fevers constituted a broad category of diseases, rather than a symptom. Rush's point, however, is that the Indians' natural savage state of society exempted them from a variety of European diseases, which only affect them now because they were introduced. So, when differentiating between the particular diseases that are endemic to the Indians' savage society and habits, he notes that "the small pox and the venereal disease were communicated to the Indians in North America by the Europeans. Nor can I find that they [the Indians] were ever subject to the scurvy. . . . The peculiar customs and manners of life among the Indians, seem to have exempted them from these, as well as all other diseases of the fluids." 24

Just as Rush connected the customs and habits of savage societies to the diseases of the American Indians, so he made the analogous point about the peculiar maladies of civilized nations. Here, interestingly enough, Rush cited the Edinburgh physician William Cullen. "The number of diseases which belong to civilized nations, according to Doctor Cullen's nosology, amounts to 1387."25 Among them, Rush names "swellings from water . . . and blood, foulness on the skin from cancers . . . and lastly the gout, the hysteria, and the hypochondriases, in all their variety of known and unknown shapes." ${ }^{26}$ Rush was not the only member of his circle to identify and locate diseases that were peculiar to the stages of civilization. Recall from the beginning of the article, Edward Miller's comments about the improvement of health as an outcome of advancement above savagery.

It is important to note, however, that in the eyes of Rush and his circle, this historical development was not always a positive one. Far from it. There was, in fact, an ambivalence, sometimes bordering on anxiety, about whether civilisation had always improved the natural state of human health. Ezekiel Ostrander, a physician educated at Edinburgh, meditated on this possibility. In his dissertation on Puerperal Fever (a septic fever contracted by the mother soon after childbirth), Ostrander noted 
with some foreboding that the tendency of civilized societies to live in cities exacerbated contagious diseases - something which savage and barbarous societies escaped. "While the human race are increasing in number, large cities augmenting, and filth and nuisance accumulating, the virulence of all diseases will be increased, their number enlarged, [such that] those that are already contagious will become more so, and those that have not been marked with contagion will, in all probability, assume a contagious character." ${ }^{27}$ Ostrander cited the work of Dr. Thomas Young, professor of midwifery and the University of Edinburgh.

Rush and his network were also interested in the correlation between social development and the useful knowledge necessary to cultivate the practice of medicine. Scots-born Peter Middleton (d. 1781), who graduated from Edinburgh and practiced in New York after immigrating to America, wrote an enquiry into the history of medicine, where he explored the practices of healing in various societies dating back to the Biblical and ancient world. He also made observations about the savage and barbarous nations of the present day, which included Native Americans and Africans. He noted the increasing esteem and status accorded to practitioners of medicine as societies became more civilized. "In short, all Nations, as they emerged from Barbarism and Ignorance, and improved in civil Polity and Knowledge, have encouraged and respected the Learned in the Healing Art; as the Friends and Benefactors of Society, and of Mankind." 28

These kinds of observations were closely related to the common belief that particular climates possessed botanical remedies peculiar for treating their diseases. In an exploration of the plant, Spirea trifoliatea, the physician Jacob de la Motta, who was educated at the Medical School at Philadelphia, described the natural history of the plant and its uses by Native Americans. He gave the Linnaean classification and cited the famous physician William Cullen's notes on the closely related plant, the ipecacuanha. ${ }^{29}$ The dried rhizomes of both plants were both expectorants and emetics: they were used to clear mucus from airways and induce vomiting. Since the late eighteenth century they have been used in a form known as syrup of ipecac.

In de la Motta's text, we find a related sentiment to the ambivalence we noted earlier about whether, in the field of medical knowledge, civilized nations are always necessarily superior to savage and rude societies. De la Motta asked, "to whom are we indebted for the discovery of some of our valuable articles; such as the Quassia Amara, Cinchona offinales? \&c. To the ingenious naturalist, or scientific physician? No! the slave, and wandering savage." 30 It is by no means clear that, even though the practice of medicine and physic was more advanced in civilized societies, the knowledge of so-called savage people - slaves and indigenous people - was necessarily inferior. In his lecture to students entitled "Observations on the Duties of a Physician and the Methods of Improving Medicine," Benjamin Rush advised his medical students that, "Negroes and Indians have sometimes stumbled upon discoveries in medicine. Be not ashamed to inquire into them." ${ }^{31}$ Rush and de la Motta's references to the knowledge acquired by non-European societies reveals that 
that some stadial theorists could actually acknowledge some of the merits of the useful knowledge accumulated by indigenous cultures. As we will see, however, this was brief historical moment.

\section{The Pacific}

When we turn to the accounts of Scottish surgeon-naturalists in the Pacific from the late eighteenth to mid-nineteenth centuries, we are able to see the recognition of the worth of indigenous knowledge gradually fade. In the late eighteenth century, this short-lived moment - in which it was possible to hold that the knowledge of some natural and "uncivilised" societies was not always inferior-also found its way to the Pacific, where some naturalists developed the idea in the context of the societies they observed, from Hawai'i in the north, to Queen Charlotte Sound, and Van Diemen's Land (Tasmania), in the south.

In the summer of 1776, William Anderson (1750-1778), a surgeon and naturalist trained at the University of Edinburgh, embarked upon the HMS Resolution, where he would serve as the surgeon and botanist on James Cook's third and final voyage, which embarked in 1776. The voyage took him to Cape Town via Tenerife, and then across to New Zealand, the Hawai'ian archipelago, and then to the Pacific coast of North America, back to Hawai'i (where Cook was killed on his final return in 1779), and then back to Plymouth. He died in the Bering Sea on August 3 1778. In his journals, Anderson commented extensively on the relative civilisation of the indigenous people he encountered in Tonga, Tahiti, and New Zealand, his thoughts framed by his Scottish training and stadial theory.

In the winter of 1777, when the Resolution sailed up the coast of Tonga, Anderson remarked upon the comparative "Industry, Ingenuity, Perserverence, [and] affability" 32 of the Tongans. Specifically, he was impressed by the Tongans' ability to progress in the mechanical arts, one of the hallmarks of useful knowledge and a marker of civilisation. "The natives of Tonga and the isles around it are upon the whole arriv'd at as much perfection in their manual works, as much regularity of their government, at as high a pitch in their agriculture and some other things as any nation whatever under the same circumstances; and that exclusive of the help obtain'd from learning the use of metals and communication with nations who have these advantages, they are in every respect almost as perfectly civiliz'd as it is possible for mankind to be." 33

What prompted Anderson's comparative respect for the civilisation of the people from Tonga was what he termed their "ingenuity" and useful knowledge, which they used to produce practical arts and tools. He was impressed that "without the use of metal ... they make very thing by which they procure their subsistence, cloathing and warlike weapons with a great degree of neatness, strength and convenience."34 Tongan material culture, in other words, signified a society capable of doing useful things with their minds and hands. The sentiment of admiration, however, was not only momentary, historically speaking, but also quite rare. For the most part, 
Scottish-trained naturalists' observations of the indigenous people of the Pacific were derogatory, precisely because of the perceived lack of development in the majority of the cultures they encountered. Stadial theory presented most Pacific peoples as lacking useful knowledge.

For Anderson, the Tongans directly contrasted to the Aborigines of Van Diemen's Land, where the Resolution landed on 26 January 1777. When Anderson gave an account of the Aborigines of Van Diemen's Land, his first observation about their state of development was that "they were even ignorant of the use of fish hooks, if we might judge from their being unable to comprehend the use of some of ours which were shown them." ${ }^{35}$ In this respect, they compared unfavourably to "the inhabitants of Terra del Fuego, who have not invention sufficient to make cloathing to defend themselves from the rigour of their climate." ${ }^{36}$

Like Anderson, the Scottish naturalist Peter Cunningham (1789-1864) also compared the various indigenous cultures he encountered, often focusing upon their abilities - or lack thereof - to cultivate useful knowledge. Cunningham had served in the Royal Navy in the Atlantic and the East Indies, as well as the Pacific. He sailed in HMS Marlborough on the coast of North America, and then in HMS Lake Erie. He then travelled with the navy to the East Indies, before making five voyages to the colony of New South Wales (later Australia) between 1817 and 1828, during which he served as the surgeon superintendent. Cunningham published his two-volume memoir, Two Years in New South Wales, in 1827.

Like Anderson, Cunningham's reflections upon the indigenous societies he encountered were firmly rooted in Scottish stadial theory. However, by the time Cunningham was writing in the 1820 s, a half-century after Anderson, the moment in which stadial discourse had a potential openness to the merits of indigenous knowledge had passed. Cunningham mused upon the differences between nomadic and settled societies and their respective forms of government. Making a general claim about uncivilised societies in language reminiscent of Adam Smith, Cunningham observed that "the first symptom of advancement in a savage body is the establishment of chiefs ... to whom all pay submission, and to whose protection they trust their persons and properties." ${ }^{37}$ Cunningham went on to compare the Aborigines with the indigenous people he had observed in both North America and the Pacific in this respect. Developing his observation about the form of government of uncivilised societies, Cunningham noted that "the North American tribes form an apt illustration of these observations," and that "the New Zealanders form an apter illustration still. ${ }^{38}$ He then went on to compare the North Americans and New Zealanders with the people of other South Sea islands that had been civilised by missionaries. "At Otaheite, the Sandwich islands, and the various other South-Sea groups now Christianized, the missionaries, by securing the good will of the absolute kings and chiefs ... ultimately obtained able assistants in converting and civilizing the body of the people." 39

Just as significant as Cunningham's reflections on the general characteristics of savagery and society, however, is the fact that when he turned to the question of what 
characterised the lack of development in the Aborigines of New South Wales, it was chiefly useful knowledge - or rather its lack thereof - that defined their lamentable situation. He observed the "great and glaring deficiency in all the useful mechanical arts (in comparison with other savages) should place them at the very zero of civilization." ${ }^{40} \mathrm{He}$ then put it explicitly, outlining his argument that the emergence of useful, practical knowledge was a direct outcome of development. "We may, I think, in great measure impute their present low state of civilisation and deficiency in the mechanical arts, to the nature of the country they inhabit, the kind of life they lead and the mode of government they live under."

\section{Conclusion}

While the foundation of Cunningham's observations about the Aborigines of New South Wales was his Scottish education in natural history and medicine, he developed and refined his ideas through his encounters with the indigenous societies in the Atlantic and the Pacific. Cunningham and William Anderson in the Pacific world, together with Benjamin Rush and his compatriots in North America, provide a window into the global legacy of the Scottish Enlightenment.

This idea of the usefulness of knowledge, I would argue, should be understood as one of the most significant cultural legacies of the era of proto-globalization. As A. G. Hopkins, C. A. Bayly, and others have argued, the period from roughly 1600 to 1800 witnessed a stage in the process of globalization defined by the expanding trading networks of European empires, and the nexus between "territory, taxation and sovereignty." 42 This era was, however, prior to industrialization and the rise of nation states, so the networks of exchange were primarily the result of trade systems, and centred upon individuals and small groups, such as those of explorers, traders, privateers, and small groups of colonial settlers. Culturally, the era witnessed what Hopkins has referred to as a "knowledge revolution, which mapped, surveyed and classified the world of contact and conquest." 43

One of the features of this knowledge revolution was the attempt to explain the social difference between European societies and the indigenous cultures they encountered. The Scottish-educated naturalists' texts I have described in this article were part of an emerging genre of ethnographic descriptions that gave substance to the idea that the pursuit of useful knowledge is a natural capacity that develops as societies progress. This idea has an enduring and global legacy. Central to contemporary understandings of the criteria of "developed" and "developing" countries is the conviction that the ability to pursue useful, practical knowledgequintessentially, modern science - is a hallmark of development. This idea was first explored and substantiated in the context of the eighteenth-century imperial networks in the Atlantic and Pacific, and it maintains its relevance as a means of defining global standards of development today. A fitting illustration is the way in which India explicitly recognised that its status as a developing nation in a global economy meant that it had to establish a "knowledge-oriented paradigm of development" in order to 
compete in the twenty-first century. In 2005, the Indian government established the National Knowledge Commission (NKC) think tank. The NKC is a twenty-first century contribution to a long tradition of relating legitimate forms of knowledge to the historical progress of human cultures. ${ }^{44}$

Further research is needed to explore the complexity of this tradition of the usefulness of knowledge, and its relationship to the forces of globalization. During the eighteenth century, as we have seen, there were occasions in which there was a certain appreciation of the merits and usefulness of indigenous knowledge. By the mid-nineteenth century, however, this appreciation was fading. Biological theories of race reconstituted and often replaced earlier ethnographic and historical approaches to human difference, thereby severely limiting European recognition of indigenous knowledge. This intellectual shift, framed by the institutionalisation of modern science, was embedded in a larger series of globalizing forces. Nineteenth-century industrialization and the rise of the nation state were so transformative of the relationships between the world's societies that the nineteenth century ushered in what Hopkins terms a new, "modern" era of globalization. European intellectual historians, and historians of science, have long been fascinated by the relationship between science and modernity. It is now clear that these are issues of global, not simply European or Western, history.

\section{Bibliography}

Anderson, William. A Journal of a Voyage Made in His Majesty's Sloop “Resolution," s.v. 16 May 1776. In The Journals of Captain James Cook on His Voyages of Discovery. Vol. 3, pt. 2, The Voyage of the Resolution and Discovery 1776-1780, edited by J. C. Beaglehole. Hakluyt Society extra series no. XXXVI. Cambridge: Cambridge University Press, 1967.

Bacon, Francis. "Of Travel." In The Major Works of Francis Bacon, edited by Brian Vickers, 374-6; 1996. Oxford: Oxford University Press, 2002.

Burnett, Linda Andersson. Northern Noble Savages?: Edward Daniel Clarke and British Primitivist Narratives on Scotland and Scandinavia, c.1760-1822. PhD diss., University of Edinburgh, 2012.

Cañizares-Esguerra, Jorge, and Erik Seeman, eds. The Atlantic in Global History 1500-2000. New York: Pearson, 2007.

Cunningham, Peter. Two Years in New South Wales: A Series of Letters, Comprising Sketches of the Actual State of Life in that Colony, of Its Peculiar Advantages to Emigrants, of Its Topographical, Natural History, etc. London: Henry Colburn, 1827.

De Acosta, José. The Natural and Moral History of the Indies, edited by Jane Mangan, translated by Frances Lopez-Morillas. Durham: Duke University Press, 2002.

De la Motta, Jacob. An Investigation of the Properties and Effects of the Spiraea Trifoliata of Linneus or Indian Physic. Philadelphia: Jane Aitken, 1810.

Ferguson, Adam. An Essay on the History of Civil Society, pt. 1, sec. 1. 1767. Reprint Philadelphia: A Finley, 1819.

- An Essay on the History of Civil Society. $2^{\text {nd }}$ ed. London: Millar and Cadell, 1768.

Findlen, Paula. Possessing Nature: Museums, Collecting, and Scientific Culture in Early Modern Italy. Berkeley: University of California Press, 1994.

Ford, Lisa. Settler Sovereignty: Jurisdiction and Indigenous People in America and Australia, 1788-1836. Cambridge: Harvard University Press, 2010. 
Gascoigne, John. Encountering the Pacific in the Age of Enlightenment. Melbourne: Cambridge University Press, 2014.

Government of India. National Knowledge Commission of India, an Overview. http://eprints. rclis.org/7462/1/National_Knowledge_Commission_Overview.pdf.

Home, Henry, Lord Kames. Sketches of the History of Man. $3^{\text {rd }}$ ed. Dublin: James Williams, 1779.

Hopkins, A. G. "The History of Globalization-and the Globalization of History?" In Globalization in World History, edited by A. G. Hopkins, 12-44. New York: Norton, 2002.

Irving, Sarah. "Rethinking Corruption: Natural Knowledge and the New World in Joseph Hall's Mundus Alter et Idem.” Journal of Early Modern European Studies 2:2 (2013): 150-68.

Jardine, Nicholas, James A. Secord, and E. C. Spary. Cultures of Natural History. Cambridge: Cambridge University Press, 1996.

Jonsson, Fredrik Albrittson. Enlightenment's Frontier: The Scottish Highlands and the Origins of Environmentalism. New Haven: Yale University Press, 2013.

Konishi, Shino. The Aboriginal Male in the Enlightenment World. London: Pickering and Chatto, 2012.

McClure, Julia. "The Poor Atlantic in Global History." Seminar paper delivered at the Harvard Global History Seminar, Cambridge, MA, January 2014.

Middleton, Peter. A Medical Discourse, or an Historical Inquiry into the Ancient and Present State of Medicine, the Substance of Which was Delivered at Opening the Medical School in the City of New-York. New York: 1769.

Miller, Edward. "Appendix." In Robert Thomas, The Modern Practice of Physic, Exhibiting the Characters, Causes, Symptoms, Prognostic, Morbid Appearances, and Improved Method of Treating the Diseases of All Climates, 657-85. $3^{\text {rd }}$ ed. New York: Collins, 1811.

Mutthu, Sankar. "Adam Smith's Critique of International Trading Companies: Theorizing Globalization in the Age of Enlightenment." Political Theory 36:2 (April 2008): 185-212.

Myers, Kathleen A., and Nina M. Scott, eds. Fernández de Oviedo's Chronicle of America: A New History for a New World. Austin: University of Texas Press, 2007.

Ostrander, Ezekiel. An Inaugural Dissertation on Puerperal Fever. Submitted to the Public Examination of the Faculty of Physic, Under the Authority of the Trustees of Columbia College in the State of New-York. The Right Rev. Benjamin Moore, D.D. President, for the Degree of Doctor of Physic, May 1804. New York: T. and J. Swords, 1804.

Randers-Pehrson, Justine. The Monros of Edinburgh and the Origins of American Medical Schools: Notes to Accompany an Exhibit at the National Library of Medicine, December 1957-January 1958. Washington, D.C.: National Library of Medicine, 1957-58.

Rush, Benjamin. An Inquiry into the Natural History of Medicine among the Indians of North America, and a Comparative View of their Diseases and Remedies, with Those of Civilized Nations. Philadelphia: Prichard and Hall, 1789.

. Observations on the Duties of a Physician and the Methods of Improving Medicine. Philadelphia: Prichard and Hall, 1789.

Sebastiani, Silvia. The Scottish Enlightenment: Race, Gender, and the Limits of Progress. New York: Macmillan, 2013.

Smith, Adam. An Enquiry into the Wealth of Nations, edited by Robert Reich. New York: Random House, 2000.

\section{Notes}

* Dr. Sarah Irving-Stonebraker is Senior Lecturer in Modern History at Western Sydney University. Her book, Natural Science and the Origins of the British
Empire, (London: Routledge, 2016 [2008]) won the Royal Society of Literature and Jerwood Foundation Award for Non-fiction. 
1 Miller, "Appendix," 686.

2 See Jardine, Secord, Emma Spary, eds., Cultures of Natural History, and Findlen, Possessing Nature: Museums, Collecting, and Scientific Culture in Early Modern Italy.

3 Irving, "Rethinking Corruption: Natural Knowledge and the New World in Joseph Hall's Mundus Alter et Idem."

4 De Acosta, The Natural and Moral History of the Indies.

5 Myers and Scott, eds., Fernández De Oviedo's Chronicle of America.

6 Bacon, "Of Travel," 374-5.

7 Ferguson, An Essay on the History of Civil Society, pt. 1, sec. 1, 11

8 Ibid., 15.

9 Home, Sketches of the History of Man, vii.

10 Ferguson, An Essay on the History of Civil Society, 173.

11 Smith, An Enquiry into the Wealth of Nations, 152.

12 Cañizares-Esguerra and Seeman, eds., The Atlantic in Global History, 15002000; none of the essays in this collection explore connections between the Atlantic and the Pacific. See also McClure, "The Poor Atlantic in Global History."

13 The exception is Lisa Ford, whose Settler Sovereignty: Jurisdiction and Indigenous People in America and Australia, 17881836, while not explicitly connecting the Atlantic and Pacific worlds, is a comparative account of conceptions of settler sovereignty in America and colonial Australia.

14 Gascoigne, Encountering the Pacific in the Age of Enlightenment; Konishi, The Aboriginal Male in the Enlightenment World; Ford, "Law"; and idem, "Before Settler Sovereignty and After Aboriginal Sovereignty: New South Wales in Global Perspective."

15 Jonsson, Enlightenment's Frontier: The Scottish Highlands and the Origins of Environmentalism; Sebastiani, The Scottish Enlightenment: Race, Gender, and the Limits of Progress; and Burnett, Northern Noble Savages?: Edward Daniel
Clarke and British Primitivist Narratives on Scotland and Scandinavia, c.17601822. Also of note is the symposium held at Linnaeus University in Sweden, Feburary 2014, entitled "Enlightenment Natural History, Stadial Theory and European Colonisation," run by Linda Andersson Burnett and Bruce Buchan.

16 Mutthu, "Adam Smith's Critique of International Trading Companies: Theorizing Globalization in the Age of Enlightenment."

17 This, in turn, was the system at Leiden, where Monro I studied. It is thought that he deliberately set up Edinburgh to emulate Leiden. See Randers-Pehrson, The Monros of Edinburgh and the Origins of American Medical Schools, 3.

18 Rush, "An Inquiry into the Natural History of Medicine among the Indians of North America," 10.

19 Ibid., 11. Incidentally, Rush makes it clear that the American Indians that he takes as his object of study are those living between the $30^{\text {th }}$ and $60^{\text {th }}$ parallels, roughly northern Florida to northern Labrador. He sometimes refers to different tribes, but he thinks that as a natural historical category, those living between those parallels exhibit a "general resemblance in the color, manners, and state of society" (ibid., 10).

20 Ibid., 17.

21 Rush's theories of mental illness - particularly his idea that it is related to modern society-mark him as ahead of his time. For the most part, the subject of mental illness emerges as a pre-occupation much later, in the discipline of psychology, and in the modernist sociology of the nineteenth century. Rush predates Emile Durkheim's Suicide, (1897), and Georg Simmel's The Metropolis and Mental Life (1903) by two centuries.

22 Rush, "An Inquiry into the Natural History of Medicine among the Indians of North America," 22.

23 Ibid., 18.

24 Ibid., 19. 
25 Ibid., 33.

26 Ibid., 33.

27 Ostrander, An Inaugural Dissertation on Puerperal Fever, viii.

28 Middleton, A Medical Discourse, 40.

29 De la Motta, An Investigation of the Properties and Effects of the Spiraea Trifoliata of Linneus or Indian Physic. Linnaean classification given on p.15. Cullen cited on p.27.

30 Ibid., 13.

31 Rush, Observations on the Duties of a Physician and the Methods of Improving Medicine, 10.

32 Anderson, A Journal of a Voyage Made in His Majesty's Sloop “Resolution," s.v. 16 May 1776, 929.
33 Ibid., 11 July 1777, 959.

34 Ibid., 25 February 1777, 812.

35 Ibid., 28 January 1777, 787.

36 Ibid., 787.

37 Cunningham, Two Years in New South Wales, 49.

38 Ibid., 50.

39 Ibid., 51.

40 Ibid., 46.

41 Ibid., 46.

42 Hopkins, "The History of Globalization —and the Globalization of History?", 5.

43 Ibid., 5.

44 Government of India, National Knowledge Commission of India, an Overview. See also http://www.knowledgecommission. gov.in/. 